\title{
Experiential Marketing Model on Hotels Owned by Regional Government of South Sumatra Province
}

\author{
Maftuhah Nurrahmi \\ University Muhammadiyah Palembang, Indonesia \\ umiulul@gmail.com
}

\begin{abstract}
Purpose of this study was to analyze hotel marketing strategies carried out by hotel owned by the South Sumatra regional government. This study was designing an experiential marketing strategy for hotels owned by the South Sumatra regional government and designing an experiential marketing model for hotels owned by the South Sumatra regional government. Research stage was divided into 3 phases, that was: analyzing the marketing strategies that had been carried out so far, designing experiential marketing strategies and designing experiential marketing models for hotels owned by the South Sumatra regional government. This study was to design experiential marketing strategies and experiential marketing models that were suitable for marketing hotels owned by regional government of the South Sumatra Province so that they could compete with other hotels in South Sumatra. Survey method by distributing questionnaires to hotel customers owned by regional government of the South Sumatra Province. Results showed that the marketing strategy used hotels owned by the South Sumatra regional government was still simple, so it required experiential marketing strategies to increase the number of occupants, and from the experiential marketing model showed that brand image affected customer satisfaction and experiential marketing affected the value of experience, where customer satisfaction and the value of experience had influences customer loyalty.
\end{abstract}

Article Info

- Received : March 20, 2019

- Revised : May 4, 2019

- Published : June 18, 2019

- No. Pages : 198-206

- DOI : 10.33019/ijbe.v3i2.166

- JEL : M31

- Keywords : experiential marketing model

\section{Introduction}

Tight competition is a challenge or threat to business people. In order to win the competition, every business person must always learn it so that it can produce creative ideas that enable products that are attractive to consumers. Hospitality business competition in Indonesia is now getting tighter with the entry of international-standard hotels into Indonesia. At present in Indonesia, there are 72 international-standard hotel brands spread throughout Indonesia (Wikipedia) such as; Accor, Aston International, Hilton Hotels, Hyatt, Ibis, Marriot, Best Western, Bajo International and so on. The more international hotels will be a threat to domestic hotels. This condition demands domestic hospitality business players to survive in very tight competition. 
In current conditions, marketers do not only rely on features and benefits as weapons, because these two things are the most easily replicated by competitors. The company also needs to prioritize customers by providing facilities that can provide satisfaction to customers. This concept also encourages people to know how much consumer loyalty to the product. Economic development causes a paradigm shift in supply, from the basis of being goods, then developing into the basics for consumers (Williams, 2006). The company is no longer enough to only provide quality services to consumers and must make extra efforts for consumers to be emotionally loyal. Experiential marketing is marketing based on what consumers feel when buying goods and services from a brand after experiencing various activities and stimulation (Schmitt, 1999) in Maghnati, et al. (2012). Experiential marketing is carried out through (1) Sensory/sense experience; (2) Feel experience (feeling or affective experience); (3) Think experience; (4) Act experience; (5) Relate experience (Schmitt, 1999) in Kustini (2007). Experiential marketing can be used effectively when applied to certain situations. There are several benefits that can be accepted and felt by a business entity according to Schmitt (1999), among others: (a) to revive a declining brand, (b) to distinguish a product from a competing product, (c) to create an image and the identity of a company, (d) to promote innovation, and (e) to persuade experiments, purchases and customer loyalty.

South Sumatra Province has 68 hotels spread throughout the area, in Palembang city has 39 hotels. There are several international hotels such as Aryaduta, Arista, Novotel, Aston and Horison hotels, then the others are domestic hotels such as Sandjaya, Sahid Imara, Swarna Dwipa, Grand Zuri, Royal Asia Hotels, Lembang, Princess and so on. The South Sumatra regional government also has six hotels, namely Swarna Dwipa hotel and Asrama in Palembang, Serelo hotel in Lahat Regency, Teluk Gelam hotel in Ogan Komering Ilir, Swarna Dwipa hotel in Muara Enim Regency and Darma Agung Pagaralam hotel. From the six hotels, only the Swarna Dwipa hotel has pretty good management, while the others according to the South Sumatra regional administration tend to be careless. Whereas in South Sumatra hotel competition is getting tighter due to the emergence of new hotels. Experiential Marketing Model in hotels owned by the South Sumatra regional government will assist in the management of hotels owned by the South Sumatra government in order to survive in very tight competition conditions. An experiential marketing strategy is an evolution of relational marketing. Experiential marketing will create experiential value that causes customers to be satisfied and willing to visit the hotel again.

\section{Literature Reviews}

Preferred Schmitt in Sudarmadi and Palupi (2001), Experiential Marketing is a marketing approach that involves consumers' emotions and feelings by creating positive experiences that are not forgotten so that consumers consume and fanatic on certain products. Elements of experiential marketing strategies are sense, feel, think, action and relate. Schmitt (1999) argues that experiential marketing can be measured using five factors (sense, feel, think, act and relate).

\section{Sense / Sensory Experience}

Sense Experience is defined as an effort to create experiences related to the five senses through sight, sound, touch, taste and smell. Where it is used to differentiate business entities and products in the market, motivate consumers to want to buy these products and deliver value to their customers.

\section{Feel / Affective Experience}


Feel Experience is a strategy and implementation to give brand influence to consumers through communication (advertising), product (packaging and contents), product identity. Every company must have a clear understanding of how to create feelings through consumption experiences that can drive consumers' imagination that consumers expect can make decisions to buy. Feel experience arises as a result of contact and interaction that develops over time, which can be done through feelings and emotions generated. Besides that, it can also be displayed through ideas and pleasure and reputation for customer service. The purpose of Feel Experience is to drive emotional stimuli (events, agents, objects) as part of feel strategies so that they can affect consumers' emotions and moods.

\section{Think / Creative Cognitive Experience}

The goal is to encourage consumers so that they are interested and think creatively so that they might produce a re-evaluation of the company and brand. Think Experience refers more to the future, focused, value, quality, and growth and can be displayed through inspirational, high technology, surprise. There are several principles contained in the think experience:

1) Surprise is an important basis in attracting consumers to creative thinking. Where surprise arises as a result if consumers feel getting something more than what is desired or expected so that satisfaction arises.

2) Intrigu, is a thought that depends on the level of knowledge, things that attract consumers, or experiences that were previously experienced by each individual.

3) Rovovacation, its nature creates controversy or surprises both pleasant and less pleasing.

\section{Act / Physical Experience and Entitle Lifestyle}

It is a marketing technique to create a consumer experience that is related to the body physically, behaviour patterns, and long-term lifestyle and experiences that occur from interaction with others. Where lifestyle is reflected in actions, interests and opinions. Act Experience in the form of a lifestyle can be applied by using ongoing trends or encouraging the creation of new cultural trends. The purpose of the act experience is to give an impression of behaviour patterns and lifestyles, as well as enrich the pattern of social interaction through the strategies undertaken.

\section{Relate / Social Identity Experience}

Relate Experience is a combination of the four aspects of experiential marketing, that was sense, feel, think and act. In general, relate experience shows relationships with other people, other groups (such as work and lifestyle) or a broader and abstract social community (e.g. country, society, and culture). The aim of relating experience is to connect these consumers with the culture and social environment reflected by the brand of a product. In addition to field problems, many similar studies have been carried out with different results. Among them according to Kusumawati (2011) examining the effect of experiential marketing on customer satisfaction and loyalty, it was found that there was a significant effect between experiential marketing variable $(\mathrm{X})$ on customer loyalty $(\mathrm{Y})$ with customer satisfaction $(\mathrm{Z})$ as an intermediate variable.

Setiabudi and Dharmayanti (2010) revealed that experiential marketing had a positive effect on customer satisfaction and customer loyalty. Then the results of research conducted by Tauli and Marhadi (2012) on the effect of emotion marketing and experiential marketing on customer loyalty indicated that independent variables namely product, equity, sense, feel, think, act and relate had a significant influence simultaneously the dependent variable was customer loyalty. Alkilani, et al. (2013) examined the effect of experiential marketing and customer satisfaction on customer commitment, the results showed that only sense and feel had a positive effect on customer satisfaction and customer satisfaction had a positive effect 
on customer commitment. Whereas think, act and relate had no significant effect on customer satisfaction.

Chao (2015) did research in the influence of experiential marketing on customer loyalty with brand image and satisfaction as an intermediate variable, indicating that experiential marketing had no significant effect on customer loyalty and brand image and satisfaction variables significantly influence customer loyalty. Ozturk (2015) examines the relationship between experiential marketing, customer satisfaction and customer loyalty, the results showed that experiential marketing had a positive and significant relationship to customer satisfaction and customer loyalty. Research conducted by Maghnati, et al. (2012) on the relationship between experiential marketing and experiential value showed that there was a positive and significant relationship between experiential marketing and experiential value.

\section{Research Methods}

A This research is a marketing management research which included: 1. Analyzing the marketing strategies for hotels owned by the South Sumatra regional government, that was the market strategy and the service marketing mix strategy. 2. Designing an experiential marketing strategy for hotels owned by the South Sumatra regional government. 3. Designing an experiential marketing model for hotels owned by the South Sumatra regional government. Outcomes from research activities: 1. Experiential marketing strategy for hotels owned by the South Sumatra regional government. 2. Experiential marketing model for hotels owned by the South Sumatra regional government. 3. Publications in international journals. 4. Draft Dissertation. Conclusive design, especially descriptive, that was research conducted to determine the value of independent variables, either one variable or more (independent) without making comparisons or linking with other variables.

Population of this study was hotel customers owned by the regional government of South Sumatra that was Swarna Dwipa hotel and Asrama Haji in Palembang, Serelo hotel in Lahat, Gunung Gare hotel in Pagar Alam and Swarna Dwipa hotel in Muara Enim. The population was infinite, so the sample would be taken as many as 350 respondents with purposive sampling technique, which was deliberate sampling because it was in accordance with the research objectives. Research material in the form of marketing management materials was conclusive that was analyzed descriptively, the results of the analysis then interacted with the research material in the form of business units of typical regional products that were empirical-descriptive which were analyzed using qualitative analysis methods. Results that had been analyzed were then interpreted and would be used as a basis for knowing hotel marketing strategies, experiential marketing strategies and explaining experiential marketing models. Then the results would be synergized with S3 dissertation entitled Service Quality, Experiential Marketing and Service Innovation on Experiential Value and Customer Satisfaction in the Hotel Sector in South Sumatra.

\section{Results}

\section{Marketing strategy for hotels owned by regional government of the South Sumatra Province}

\section{Market Strategy}

Based on the results of the research showed that the characteristics for hotels owned by the South Sumatra regional government when viewed from the reason for staying the most was due to holidays (47\%), based on the highest gender of women $(52.5 \%)$, the most marriage 
statuses were married $(75.5 \%)$ and based on most jobs were private employees $(52.5 \%)$ During this time the Swarna Dwipa, Serelo and Serasan Sekundang hotels were mostly guests because of official service. While Gunung Gare and Seganti Setungguan hotels were in addition to official activities for tourism.

1) Product Strategy

The strategy of hotel products owned by the South Sumatra regional government in the form of renting hotel rooms, villas and meeting hall. Facilities provided by standard three-star hotels, such as rooms equipped with beds, air conditioning, television and wifi, for the Serelo Lahat and Swarna Dwipa Palembang hotels were equipped with a swimming pool.

2) Price Strategy

Price strategies for hotels owned by the South Sumatra regional government were based on competition. Hara set was equivalent to the price of other three-star hotels. Only the Serelo Lahat hotel set prices a little lower than other hotels and used psychological prices by setting odd prices.

3) Promotion Strategy

Promotion strategies for hotels owned by the South Sumatra government used promotional mix in the form of advertisements via the internet and brochures.

4) Place Strategy

Hotels in the South Sumatra regional government are all strategically located. Swarna Dwipa Hotel is in the centre of Palembang city which is close to government centres and shopping locations. Likewise, the Serelo hotel is located in the centre of Lahat city and the hotel Serasan Sekundang is also located on the main road of Muara Enim City Lahat. Whereas Gunung Gare and Seganti Setungguan hotels are located in tourist areas and Pagar Alam plantations, which are located on the slopes of Mount Dempo, the air is cool.

5) Service Strategy

South Sumatra regional government hotels provided adequate services such as clean rooms, comfortable lobbies, spacious parking, a fairly complete and tasty breakfast, friendly and responsive employees. For the five government-owned hotels that had the same service standards, only the Seganti Setungguan hotel whose breakfast was less complete.

6) Physical environment

The interior and exterior design ofor hotel owned by the South Sumatra regional government was simple, because of most of the old buildings. Even for hotels, Serasan Sekundang building was not well maintained. As for the others, even though the building was an old model but it was quite well maintained. The environment around the hotel was quite comfortable, especially for Gunung Gare and Seganti Setungguan the surrounding environment was very convenient because it was on the slopes of the mountains.

An experiential marketing strategy for hotels owned by regional government of the South Sumatra Province

Marketing strategies carried out by hotels owned by the South Sumatra regional government had not been able to increase the number of occupancies. So that the hotel needed a strategy that could increase customer satisfaction.

1) Sense experience

The strategy of sense experience in hotels owned by the South Sumatra government could be done by raising local culture and wisdom, such as welcoming guests with dances and music typical of South Sumatra. Vision appeal for example by attaching 
photos of tourist destinations on the walls of the hotel, displaying decorations that were local handicraft products, such as songket, jumputan, purun, rattan and so on as an attraction in the hotel room or lobby. Employees used typical uniforms in South Sumatra. Hearing appeal for example by playing music and songs typical of the region of South Sumatra. Then from the appeal of taste for breakfast dishes could be served a typical regional menu such as Pempek, Burgo, Laksan, Celimpungan, Tekwan and cakes typical of South Sumatra, with the appeal of the five senses were expected to create an unforgettable impression so that customers would return to stay in the future.

2) Feel experience

The hotel identity would also be better to use local identities such as sandals, soap, shampoo, toothpaste and toothbrushes given an identity that made it easy for consumers to remember the identity of the hotel. Hotels also needed to communicate their services to consumers through the internet, brochures still needed to be done. Reputation of service might be improved by providing impressive services, by providing convenience in the management procedures, friendly and pleasant services and maintaining security in the hotel environment.

3) Think experience

Giving consumers a surprise or surprise gift, for example, associated with a consumer's birthday, company anniversary or other big days. Conduct inspirational activities that inspired positive associations, for example by commemorating major holidays.

4) Act experience

Hotels in the South Sumatra regional government needed to create a new cultural trend that elevated local culture so that all guests would always be reminded and repeat their stay at the hotel. The identity of the hotel, the attractiveness of the interior, the food menu, the music, the hospitality of its employees would be imprinted on consumers' memories.

5) Relate experience

Combining these four experiences was to provide value to experiences that satisfied consumers, that was with five sensory experiences, behavioural experience, experience of knowledge and physical experience.

An experiential marketing model for hotels owned by the South Sumatra regional government.

Based on the results of the analysis, the following could be interpreted:

1. Model Match Analysis

Table 1. Model Match Analysis

\begin{tabular}{|l|l|c|c|c|}
\hline No & Goodness of Fit Index & Cut off Value & Analysis Results & Decision \\
\hline 1 & Chi-Square & Smaller than Chi-Square Table & & \\
\hline 2 & Significance Probability & $>0,05$ & 0,0026 & Not Fit \\
\hline 3 & GFI & $>0,90$ & 0,94 & Fit \\
\hline 4 & AGFI & $>0,90$ & 0,89 & Not Fit \\
\hline 5 & CFI & $>0,95$ & 0,99 & Fit \\
\hline 6 & NFI & $>0,90$ & 0,98 & Fit \\
\hline 7 & SRMR & $<0,05$ & 0,035 & Fit \\
\hline 8 & RMSEA & $<0,08$ & 0,049 & Fit \\
\hline
\end{tabular}

From the table above, it could be concluded that almost the overall size of the match states that the data used was fit. So that it could be continued as data analysis. 
Confirmatory Factor Analysis (CFA)

Based on the results of the CFA analysis, the data obtained that some dimensions had a low value which caused the data to be unreliable (VE value was lower than 0.5 ) so that the data was removed from the model.

Following are the results of the CFA analysis:

Table 1. CFA analysis

\begin{tabular}{|c|c|c|c|}
\hline VARIABLE & S.LOAD & S.LOAD^2 & $1-$ S.LOAD`2 $^{\wedge}$ \\
\hline \multicolumn{4}{|c|}{ Customer experience marketing variable } \\
\hline $\mathrm{X} 1.3$ & 0,55 & 0,30 & 0,70 \\
\hline $\mathrm{X} 1.4$ & 0,85 & 0,72 & 0,28 \\
\hline $\mathrm{X} 1.5$ & 0,66 & 0,44 & 0,56 \\
\hline Total & 2,06 & 1,4606 & 1,5394 \\
\hline $\operatorname{Total}^{\wedge} 2$ & \multicolumn{2}{|c|}{4,2436} & \\
\hline \multicolumn{4}{|l|}{ Brand image variable } \\
\hline $\mathrm{X} 2.1$ & 0,73 & 0,53 & 0,47 \\
\hline $\mathrm{X} 2.2$ & 0,83 & 0,69 & 0,31 \\
\hline $\mathrm{X} 2.3$ & 0,79 & 0,62 & 0,38 \\
\hline Total & 2,35 & 1,85 & 1,15 \\
\hline $\operatorname{Total}^{\wedge} 2$ & \multicolumn{2}{|c|}{5,5225} & \\
\hline \multicolumn{4}{|l|}{ Satisfaction variable } \\
\hline Y1.1 & 0,77 & 0,59 & 0,41 \\
\hline Y1.2 & 0,86 & 0,74 & 0,26 \\
\hline Y1.5 & 0,52 & 0,27 & 0,73 \\
\hline Total & 2,15 & 1,60 & 1,40 \\
\hline Total$^{\wedge} 2$ & \multicolumn{2}{|c|}{4,6225} & \\
\hline \multicolumn{4}{|l|}{ Experience value } \\
\hline \multicolumn{4}{|l|}{ Y2.1 } \\
\hline $\mathrm{Y} 2.2$ & 0,56 & 0,31 & 0,69 \\
\hline Y2.3 & 0,79 & 0,62 & 0,38 \\
\hline Y2.4 & 0,79 & 0,62 & 0,38 \\
\hline Total & 2,14 & 1,56 & 1,44 \\
\hline $\operatorname{Total}^{\wedge} 2$ & \multicolumn{2}{|c|}{4,5796} & \\
\hline \multicolumn{4}{|l|}{ Loyalty variable } \\
\hline Z.1 & 0,73 & 0,53 & 0,47 \\
\hline $\mathrm{Z} .2$ & 0,78 & 0,61 & 0,39 \\
\hline $\mathrm{Z} .3$ & 0,72 & 0,52 & 0,48 \\
\hline \multicolumn{4}{|l|}{$\mathrm{Z} .4$} \\
\hline Total & 2,23 & 1,66 & 1,34 \\
\hline Total $^{\wedge} 2$ & \multicolumn{2}{|c|}{4,9729} & \\
\hline CR & 0,8 & & \\
\hline VE & 0,6 & & \\
\hline
\end{tabular}

2. Full Model 


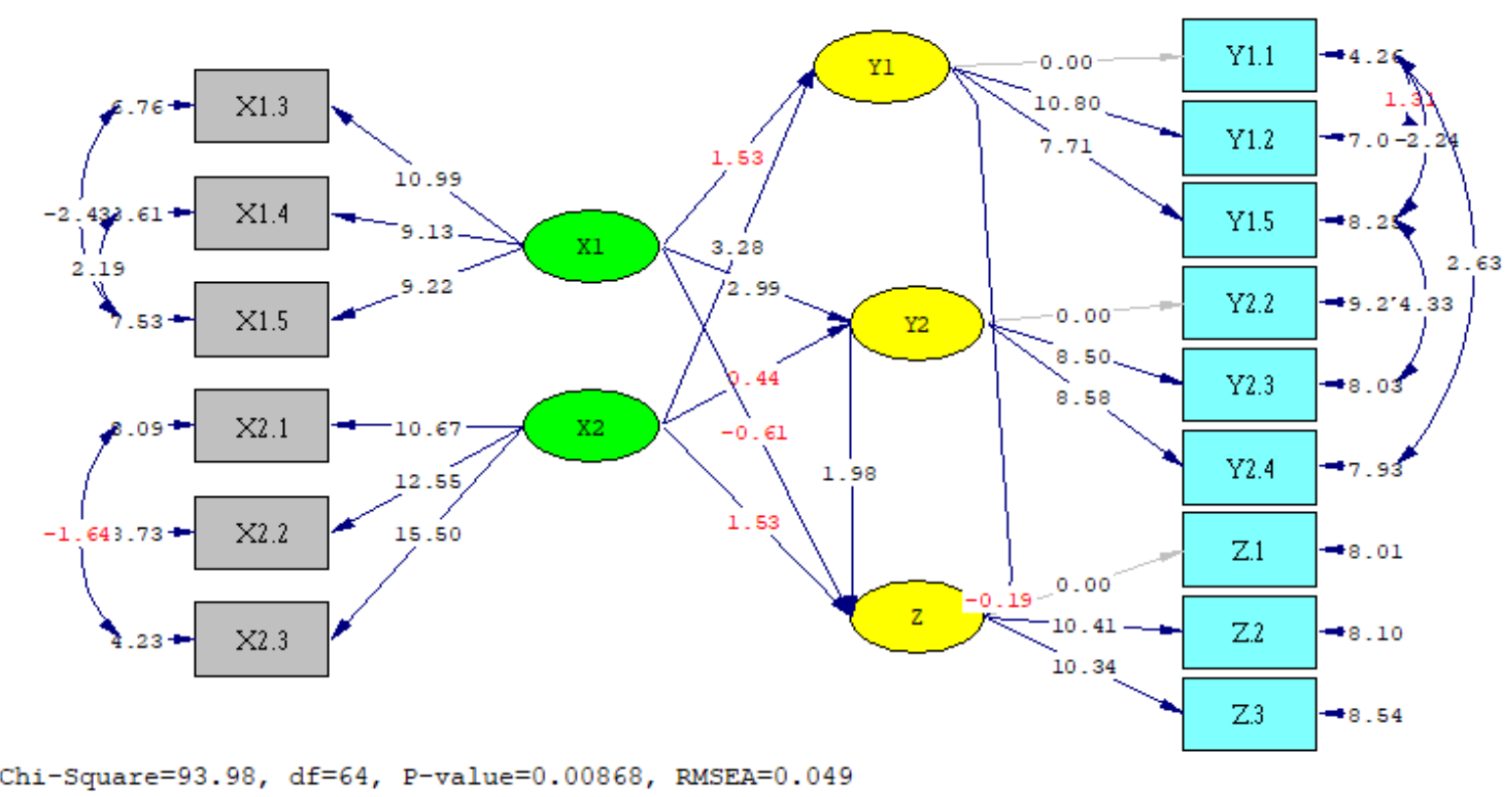

Figure 1. Full model SEM

Based on the results of data analysis, all parameters in the whole model were significant $(\mathrm{t}$ obtained value was greater than 1.96). The detailed interpretation of the analysis model would be explained below.

Based on the results of the analysis, the structure equation could be described below.

$\mathrm{Y} 1=0.30 * \mathrm{X} 1+0.64 * \mathrm{X} 2$

$\mathrm{Y} 2=0.83 * \mathrm{X} 1+0.12 * \mathrm{X} 2$

$\mathrm{Z}=-0.044 * \mathrm{Y} 1+0.96 * \mathrm{Y} 2-0.34 * \mathrm{X} 1+0.40 * \mathrm{X} 2$

The equation model above shows that:

a) Consumer satisfaction (Y1) was directly influenced by the brand image variable (X2) positively and significantly. While the customer experience marketing (X1) variable did not significantly affect customer satisfaction.

b) Experience value (Y2) was directly influenced by customer experience marketing (X1) variables positively and significantly. while brand image (X2) did not significantly affect the value of experience.

c) Loyalty (Z) was directly influenced by the value of experience (Y2) positively, while the variables of customer satisfaction, customer experience marketing, and brand image were not significant. Indirectly customer experience marketing had a positive and significant influence on loyalty through the value of experience while the brand image variable was not significant. Indirectly through customer satisfaction, customer experience marketing variables and brand image were not significant.

Consumer loyalty was influenced by customer satisfaction, convenience, experience, trust and pride. Based on preliminary research on consumer loyalty for hotels owned by the South Sumatra government due to ease and trust. Therefore, in the study of experiential marketing models, the variables of brand image (pride), marketing experience, value of experience, customer satisfaction and customer loyalty were taken. Based on these results indicated that brand image affected satisfaction and marketing experience affected the value of experience. This showed that pride in brands would affect satisfaction, so it was very important for hotels owned by government to build a positive image of the brand. While the marketing experience would shape the value of experience, it meant that companies owned by government needed 
to provide an impressive experience for consumers, because this impressive experience would shape consumer loyalty. Although brand image and marketing experience did not have a direct effect on loyalty, it would indirectly shape loyalty.

\section{Conclusion and Suggestion}

\section{Conclusions}

a) The marketing strategy of hotels owned by the South Sumatra regional government was still very simple so it had not been able to increase the number of occupancies.

b) Experiential marketing strategy was needed for hotels owned by the South Sumatra regional government by providing an impressive experience that would give value to experience for customers.

c) Obtain an experiential marketing model that was suitable for hotels owned by the South Sumatra regional government.

\section{Suggestions}

a) Hotels owned by the South Sumatra regional government needed to renew marketing strategies.

b) Implementing experiential marketing strategies was by raising local culture and wisdom.

c) Improve brand image was by building a positive image and pride in the brand.

d) Improve customer satisfaction was by an impressive value of customer experience.

\section{References}

1) Alkilani, K., Ling, K. C., \& Abzakh, A. A. (2017). The Impact of Experiential Marketing and Customer Satisfaction on Customer Commitment in the World of Social Networks. Asian Sosial Science, 9(1), 262-270. https://doi.org/10.5539/ass.v9n1p262

2) Andreani, F. (2007). Experiential Marketing (Sebuah Pendekatan Pemasaran). Jurnal Manajemen Pemasaran Fakultas Ekonomi Universitas Kristen Petra, 2(1), 1-8. https://doi.org/10.9744/pemasaran.2.1.

3) Chao, R. (2015). The Impact of Experimental Marketing on Customer Loyalty for Fitness Clubs : Using Brand Image and Satisfaction as the Mediating Variables. Journal of International Management Studies, 10(2), 52-60.

4) Kusumawati, A. (2011). Analisis Pengaruh Experiential Marketing terhadap Kepuasan Pelanggan dan Loyalitas Pelanggan: Kasus Hypermart Malang Town Square (Matos). Jurnal Manajemen Pemasaran Modern, 3(1), 75-86.

5) Maghnati, F., Ling, K. C., \& Nasermoadeli, A. (2012). Exploring the Relationship between Experiential Marketing and Experiential Value in the Smartphone Industry. International Business Research, 5(11), 169-177. https://doi.org/10.5539/ibr.v5n11p169.

6) Öztürk, R. (2015). Exploring the Relationships between Experiential Marketing, Customer Satisfaction and Customer Loyalty: An Empirical Examination in Konya. International Journal of Social, Behavioral, Educational, Economic, Business and Industrial Engineering, 9(8), 28172820.

7) Setiabudi, R., \& Dharmayanti, D. (2010). Analisa Hubungan Experiential Marketing, Kepuasan Pelanggan, Loyalitas Pelanggan Starbucks Coffee di Surabaya Town Square. Jurnal Manajemen Pemasaran, 2(2).

8) Tauli, O., \& Marhadi. (2012). Pengaruh Emotion Marketing dan Experiential Marketing terhadap Customer Loyalty Pondok Khas Melayu di Pekanbaru. Jurnal Ekonomi, 20, 1-18. 